*ak RMIS View/Frint Document Cover Sheet tow

This document was retrieved from the Documentation and Records Manaqement (DRM) ISEARCH System. It is intended for Information only and may not be the most recent or updated version. Contact a Document Service Center (see Hanford Info for locations) if you need additional retrieval information.

Accession \#: D196027033

Document \#: SD-WM-TI-735

Title/Desc:

HLW PROCESS \& PRODUCT DATA ANNOTATED BIBLIOGRAPHY

Pages: 28 


\begin{tabular}{|l|l|}
\hline $\begin{array}{l}\text { 2. To: (Receiving Organization) } \\
\text { High-Level Waste Program }\end{array}$ & $\begin{array}{l}\text { 3. From: (Originating Organization) } \\
\text { TWRS Process Technology }\end{array}$ \\
\hline $\begin{array}{l}\text { 5. Proj./Prog./Dept./Div.: } \\
\text { Tank Waste Remediation }\end{array}$ & $\begin{array}{l}\text { 6. Cog. Engr.: } \\
\text { System }\end{array}$ \\
\hline
\end{tabular}

8. Originator Renarks:

For approval and release.

3. From:
TWRS Pro
6. Cog. Eng
G. E. St
376-5548
2. To: (Receiving Organization)

5. Proj./Prog./Dept./Div.:

11. Receiver Renarks:
4. Related EDT No.:

NA

7. Purchase Order No.:

NA

9. Equip./Component No.: NA

10. System/Bldg./Facil ity:

NA

12. Major Assm. Dwg. No.: NA

13. Permit/Permit Application No.: NA

14. Required Response Date:

NA

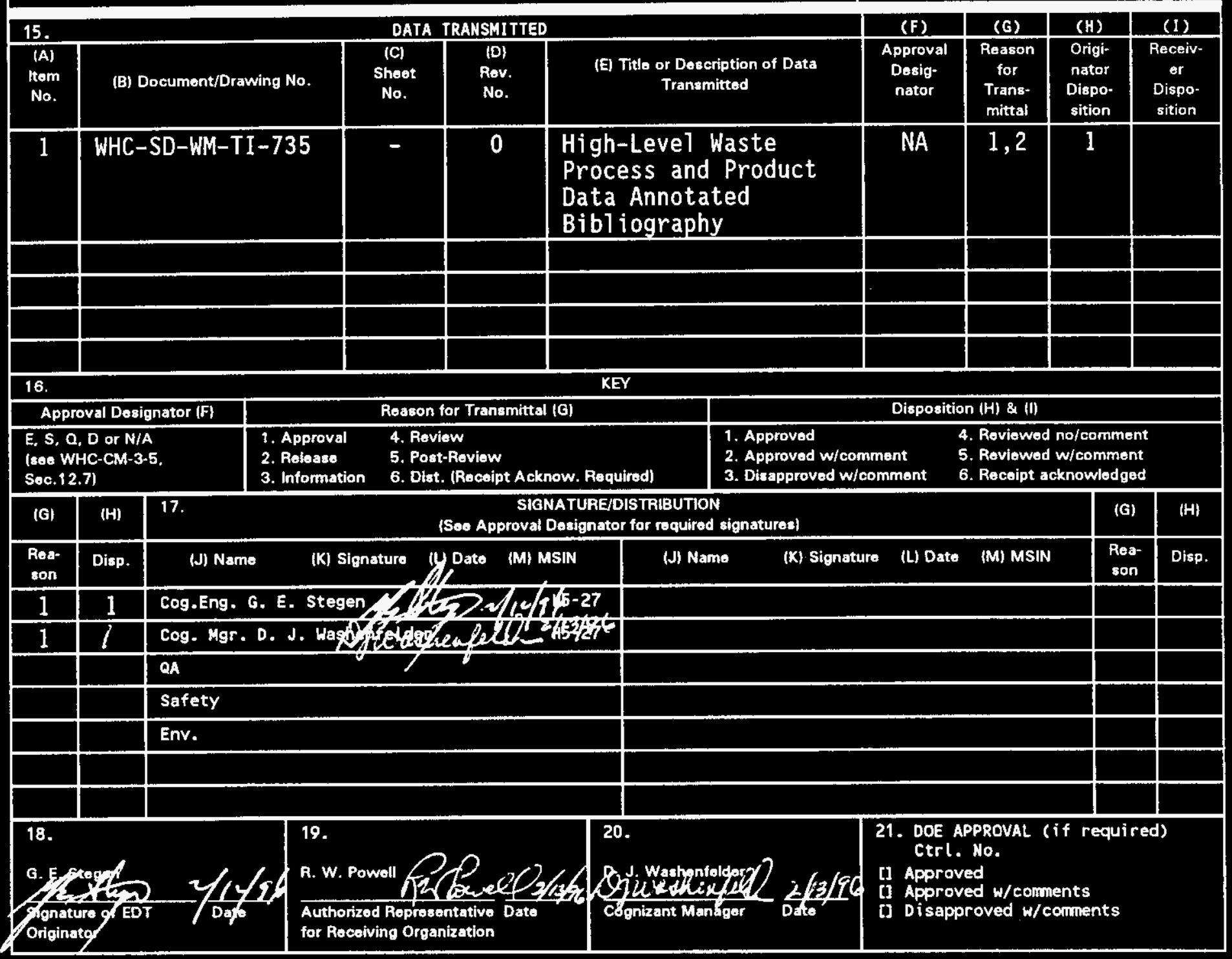

BD-7400-172-2 (04/94) GEF097 


\section{High-Level Waste Process and Product Data Annotated Bibliography}

\section{G. E. Stegen}

Westinghouse Hanford Company, Richland, WA 99352

U.S. Department of Energy Contract DE-ACO6-87RL10930
EDT/ECN: 608993
UC: 721
Org Code: 73510
Charge Code: D5228
B\&R Code: EW3130010 Total Pages: 25

Key Words: bibliography, high-level waste

Abstract: The objective of this document is to provide information on available issued documents that will assist interested parties in finding available data on high-level waste and transuranic waste feed compositions, properties, behavior in candidate processing operations, and behavior on candidate product glasses made from those wastes. This initial compilation is only a partial list of available references.

TRADEMARK DISCLAIMER. Reference herein to any specific comercial product, process, or service by trade name, trademark, manufacturer, or otherwise, does not necessarily constitute or imply its endorsement, recommendation, or favoring by the United States Government or any agency thereof or its contractors or subcontractors.

Printed in the United States of America. To obtain copies of this document, contact: WHC/BCs Document Control Services, P.0. Box 1970, Mailstop 46-08, Richland WA 99352, Phone (509) 372-2420; Fax (509) 376-4989.
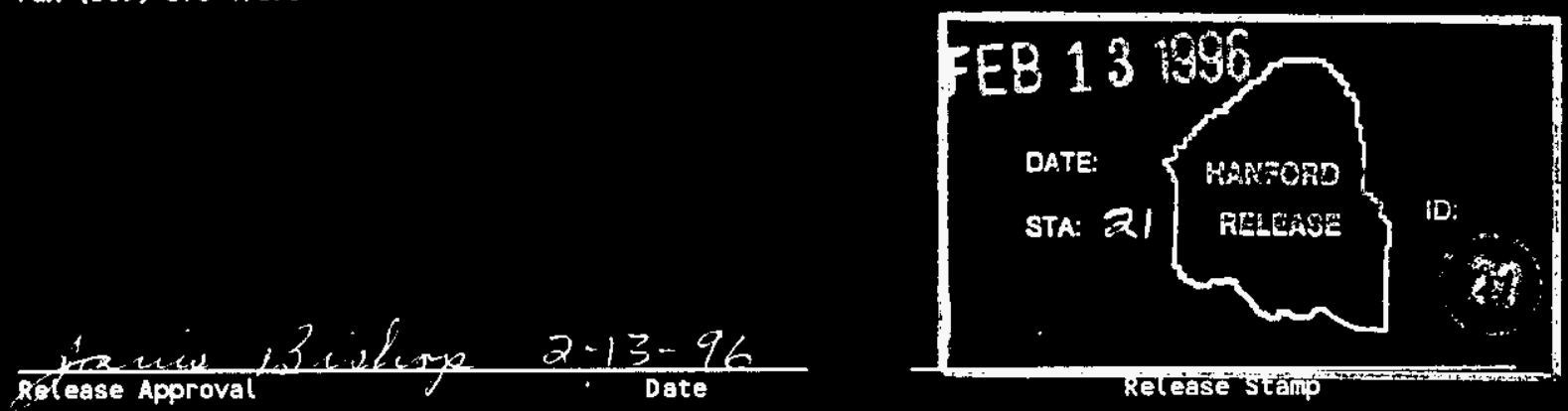

\section{Approved for Public Release}


WHC-SD-WM-TI-735

Revision 0

\title{
HIGH-LEVEL WASTE PROCESS AND PRODUCT DATA ANNOTATED BIBLIOGRAPHY
}

\author{
G. E. Stegen
}

February 1996

Westinghouse Hanford Company

Richland, Washington 
WHC-SD-WM-TI-735

Revision 0

This page intentionally left blank. 
WHC-SD-WM-TI-735

Revision 0

\section{HIGH-LEVEL WASTE PROCESS \\ AND PRODUCT DATA \\ ANNOTATED BIBLIOGRAPHY}

\subsection{INTRODUCTION}

A processing plant is planned to immobilize the high-level waste (HLW) and transuranic (TRU) fraction of tank wastes produced by defense activities at the Hanford Site. Tank wastes were generated over an extended period beginning the mid-1940s, and are currently stored in underground tanks. Before processing for HLW immobilization, the wastes will be processed (pretreated) to remove most of the inert components to reduce final volume of immobilized HLW to be produced. High-level and TRU residues from pretreatment will be immobilized by melting them together with additives, to form a durable vitreous waste form (glass).

A two-phase program has been proposed to immobilize the waste. Phase I is a proof of principal phase expected to immobilize only a few percent of the currently stored HLW and TRU waste. Four tanks currently are designated as source tanks for HLW to be immobilized in Phase I (241-AZ-101, 241-AZ-102, 241-AY-102, and 241-C-106). There also is a possibility that other waste sources could be considered as substitutes or supplements to waste from these four tanks during Phase I. In Phase II, the balance of the HLW and TRU tank waste will be processed at a substantially higher rate.

Historical production records and limited sampling of the underground waste storage tanks provide some information on composition and characteristics of the stored waste. However, there is uncertainty as to some characteristics of the wastes, particularly in regard to the older single-shell tank (SST) wastes.

\subsection{SCOPE AND OBJECTIVE}

A substantial amount of technical information has been developed over the years on composition and characteristics of tank wastes, behavior of HLW feeds in candidate waste treatment processes, and properties of candidate product glass waste forms. A large fraction of this information is a product of U.S. Department of Energy (DOE) sponsored work, including work at the Hanford Site, Savannah River Site, and the West Valley Demonstration Project (WVDP). Some of the information has been published in open literature, while a substantial fraction is in internal documentation. Some information is unpublished, such as data recorded only in laboratory notebooks or unissued draft reports. 


\section{Revision 0}

The objective of this document is to provide a bibliography of issued, publicly available documents that will assist interested parties in finding available data on HLW and TRU waste feed compositions, properties, behavior in candidate processing operations, and behavior on candidate product glasses made from those wastes. This initial compilation is only a partial list of available references. A separate companion bibliography is being prepared by Pacific Northwest National Laboratory (PNNL) to cover potentially useful PNNL references from the relatively large amount of work performed for the Hanford Waste Vitrification Project (HWVP) (Larson 1996). In future updates, it is planned to merge the bibliography herein with the PNNL developed bibliography and to expand the bibliography both in terms of references and annotations.

The bibliography is focused primarily on results of DOE sponsored work at the Hanford Site. However, some references from other DOE sites and a limited number of additional outside references are included that have been found in past work to provide some valuable information in this subject. For selected references, annotations have been included to assist in identifying contents and applicability.

The references are organized into four major groupings. References included in Section 3.0 are primarily related to Phase I and Phase II tank waste composition, waste quantity, waste sludge behavior during water washing or caustic digestion pretreatment processes, and effect of blending HLW feeds. References in Section 4.0 are primarily related to feed behavior in candidate immobilization processes, properties and behavior of immobilized waste forms, process and equipment performance, and process technology evaluations. References in Section 5.0 are related to processes for removal of radionuclides from liquid tank waste. The high activity product from these processes may represent a portion of the feed to the HLW immobilization process. References in Section 6.0 include: integrated Hanford Site waste management system studies, process facility options studies, process system studies and flowsheets, process and facility design requirements documents, policy type documents, and miscellaneous supporting documents.

A large fraction of available data has been developed using non-radioactive simulants intended to mimic the behavior and properties of actual waste. The reader needs to be aware that the simulants do not always accurately mimic actual waste properties and behavior. 
WHC-SD-WM-TI-735

Revision 0

\subsection{TANK WASTE COMPOSITION, QUANTITY, AND SLUDGE PRETREATMENT}

Agnew, S. F., 1995, Hanford Defined Wastes: Chemical and Radionuclide Compositions, LA-UR-94-2657, Rev. 2, Los Alamos National Laboratory, Los Alamos, New Mexico.

Anderson, J. D., 1990, A History of the 200 Area Tank Farms, WHC-MR-0132, Westinghouse Hanford Company, Richland, Washington.

Certa, P. J., 1995, Preliminary Retrieval Sequence and Blending Strategy, WHC-SD-WM-RPT-167, Rev. 0, Westinghouse Hanford Company, Richland, Washington.

Notes: Evaluates effects of alternate Hanford Site tank waste retrieval and blending scenarios, including effect on estimated achievable volume of HLW glass produced.

Colton, N. G., 1995, Sludge Pretreatment Chemistry Evaluation: Enhanced Sludge Washing Separation Factors, PNL-10512, Pacific Northwest Laboratory, Richland, Washington.

Notes: Review of FY 1994 test data on pretreatment of Hanford Site tank waste solids samples.

Geeting, J. G. H., and D. E. Kurath, 1993, Preliminary Assessment of Blending Hanford Tank Wastes, PNL-8589, Pacific Northwest Laboratory, Richland, Washington.

Hanlon, B. M., 1994, Tank Farm Surveillance and Waste Status Summary Report for October 1993, WHC-EP-0182-67, Westinghouse Hanford Company, Richland, Washington.

Notes: Provides a summary of current Hanford Site double-shell tank (DST) and SST waste volume estimates by tank in categories of supernate, sludge, salt cake, and drainable liquid.

Hara, F. T., J. H. Kaye, R. T. Steele, R. W. Stromalt, D. L. Thoman, and M. W. Urie, 1990, SST Sample Characterization Analysis of Archive Samples 102-C, 105-C, and 106-C, PNL-7258, Pacific Northwest Laboratories, Richland, Washington.

Notes: Report of chemical and radioisotope analyses of a waste sample from waste tanks including 241-C-106. The sample is from the same core as the Weiss report and the McCown report, however, the exact history of the sample is not determined. Some additional unpublished data are available on this sample analysis. 
Hill, J. G., and B. C. Simpson, 1994, The Sort on Radioactive Waste Type Model: A Method to Sort Single-Shell Tanks into Characteristic Groups, PNL-9814, Pacific Northwest Laboratory, Richland, Washington.

Hodgson, K. M. and T. T. Tran, 1995, Tank Characterization Report for Double-Shell Tank 241-AZ-101, WHC-SD-WM-ER-410, Rev. 0-A, Westinghouse Hanford Company.

Jungfleisch, F. M., 1984, TRAC: A Preliminary Estimation of the Waste Inventories in Hanford Tanks Through 1980, SD-WM-TI-057, Rockwell Hanford Operations, Richland, Washington.

Lambert, S. L., and D. S. Kim, 1994, Tank Waste Remediation System High-Level Waste Feed Processability Assessment Report, WHC-SP-1143, Rev. 0, Westinghouse Hanford Company, Richland, Washington.

Notes: Study evaluates effect of feed composition on performance of the HLW vitrification process, primarily focussing on glass quantity. Includes evaluation of effect of feed blending and melter temperature on glass quantity.

Lumetta, G. J., M. J. Wagner, R. J. Barrington, B. M. Rapko, and C. D. Carlson, 1994, Sludge Treatment and Extraction Technology Development: Results of FY 1993 Studies, PNL-9387, Pacific Northwest Laboratory, Richland, Washington.

Manuel, A. F., J. D. Galbraith, S. L. Lambert, and G. E. Stegen, 1996 Phase 1 High-Level Waste Pretreatment and Feed Staging Plan, WHC-SD-WM-ES-370, Rev. 0, Westinghouse Hanford Company, Richland, Washington.

Peterson, M. E., R. D. Sheele, and J. M. Tingey, 1989, Characterization of the First Core Sample of Neutralized Current Acid Waste from Double-Shell Tank 101-AZ, PNL-7758, Pacific Northwest Laboratory, Richland, Washington.

Notes: Report of analysis of a core sample of sludge from tank 241-AZ-101 taken in 1989. Report includes chemical composition, radioisotope composition, physical properties, rheology, solids settling rates. Results of water washing the sludge are also reported.

Rapko, B. M., G. J. Lumetta, and M. J. Wagner, 1995, Washing and Caustic Leaching of Hanford Tank Sludges: Results of FY 1995 Studies, PNL-10712, Pacific Northwest National Laboratory, Richland, Washington.

Notes: Report the results of water washing and caustic digestion tests on a number of different types of tank waste sludges. Includes chemical and radiochemical analyses on the sludges and leach or wash solutions. 


\section{Revision 0}

Ryan, G. W. and T. T. Tran, 1995, Tank Characterization Report for Double-Shell Tank 241-AZ-102, WHC-SD-WM-ER-411, Rev. 0-A, Westinghouse Hanford Company, Richland, Washington.

Ryan, G. W., 1995, Tank Characterization Report for Double-Shell Tank 241-AY-102, WHC-SD-WM-ER-454, Rev. 0, Westinghouse Hanford Company, Richland, Washington.

Weiss, R. L. and K. E. Schull, 1991, Data Transmittal Package for 241-C-106 Waste Tank Characterization, WHC-SD-RE-TI-205, Rev. 0, 1988, modified by ECN 164206, September 28, 1991, approved for Public Release August 11, 1992, Westinghouse Hanford Company, Richland, Washington.

Notes: Contains information on core sampling of Tank 241-C-106 performed in 1986, physical description of core sample material, and results of laboratory analysis of a blended composite of the core sample. Additional analysis on the same core sample are reported in PNL-7258 (Hara et al. 1990).

WHC, 1995a, Historical Tank Waste Content Estimate for the Southeast Quadrant of the Hanford 200 West Area, WHC-SD-WM-ER-350, Rev. 0, Westinghouse Hanford Company, Richland, Washington.

WHC, 1995b, Historical Tank Waste Content Estimate for the Northwest Quadrant of the Hanford 200 West Area, WHC-SD-WM-ER-351, Rev. 0, Westinghouse Hanford Company, Richland, Washington.

WHC, 1995c, Historical Tank Waste Content Estimate for the Southeast Quadrant of the Hanford 200 East Area, WHC-SD-WM-ER-352, Rev. 0-A, Westinghouse Hanford Company, Richland, Washington.

WHC, 1995d, Historical Tank Waste Content Estimate for the Northeast Quadrant of the Hanford 200 West Area, WHC-SD-WM-ER-349, Rev. 0-A, Westinghouse Hanford Company, Richland, Washington. 
WHC-SD-WM-TI-735

Revision 0

\title{
4.0 IMMOBILIZATION PROCESS, SUPERNATE PRETREATMENT PROCESS, AND IMMOBILIZED PRODUCT BEHAVIOR REFERENCES
}

\author{
Andrews, M. K. and N. E. Bibler, 1992, Radioactive Demonstration of DWPF Product \\ Control Strategy, Ceramic Transactions, Vol. 39, pp. 205-211, American Ceramic \\ Society, Westerville, Ohio.
}

Notes: Summary of the results of glass production from washed tank 51 waste. About $31 \mathrm{~kg}$ of glass was produced from $10 \mathrm{~kg}$ (dry basis) actual tank sludge. Paper gives chemical composition, and Product Consistency Test durability results and also gives information on use of the Product Composition Control System models to formulate feed.

Andrews, M. K., et al., 1991, Initial Demonstration of the DWPF Vitrification Process and Product Control Strategy Using Actual Radioactive Waste, Nuclear Waste Management IV, pp. 569-576, American Ceramic Society, Westerville, Ohio.

Notes: $25 \mathrm{~kg}$ of glass was made from $12.5 \mathrm{~kg}$ actual radioactive waste sludge from tanks 8 and 12 using an 8 -in. diameter by 6 -in. deep Joule heated melter at $1150^{\circ} \mathrm{C}$. Predicted and measured composition and PCT leach rate data are presented, measured leach rate was 2 to 3 times the predicted values based on the prediction model in use at that time, a trace ( $<1$ percent) of spinel crystals were also detected in the glass.

Barnes, S. M., 1980, High-Temperature Vitrification of Hanford Residual-Liquid Waste in a Continuous Melter, PNL-3343, Pacific Northwest Laboratory, Richland, Washington.

Notes: Testing with a high temperature melter with tin oxide electrodes, high sodium feed, 1250 to $1300{ }^{\circ} \mathrm{C}$ operating temperature, measured cesium loss to offgas $(<1$ percent).

Barnes, S. M., and D. E. Larson, 1981, Materials and Design Experience in a Slurry-Fed Electric Glass Melter, PNL-3959, Pacific Northwest Laboratory, Richland, Washington.

Bibler, N. E., 1983, Characterization of Borosilicate Glass Containing Savannah River Plant Radioactive Waste. II. Microstructure and Durability, DP-MS-82-111, Savannah River Laboratory, Aiken, South Carolina.

Bickford, D. F., and C. M. Jantzen, 1986, "Devitrification of Defense Nuclear Waste Glasses: Role of Insolubles," Journal of Non-Crystalline Solids, Vol. 84, No. 1-3, pp. 299-307. 
Bickford, D. F. and A. S. Choi, 1991, Control of High Level Radioactive Waste-Glass Melters-Part 5: Modelling of Complex Redox Effects, Proceedings of the Fifth International Symposium on Ceramics in Nuclear and Hazardous Waste Management, Vol. 23 pp.267-281, April 29 through May 3, 1991, Westerville, Ohio.

Notes: Discusses redox effects in glass melting, formation and precipitation of nickel sulfide including estimated oxygen potential at point of incipient sulfide formation and corresponding $\mathrm{H} 2 / \mathrm{H} 2 \mathrm{O}$ and $\mathrm{CO} / \mathrm{CO} 2$ and $\mathrm{Fe}+2 / \mathrm{Fe}+3$ ratios, concludes reasonable limit is to keep pO2 $>\mathrm{E}-8$ and $\mathrm{Fe}+2 / \mathrm{Fe}+3<1$.

Bickford, D. F., A. Applewhite-Ramsey, C. M. Jantzen, and K. G. Brown, 1990, "Control of Radioactive Waste Glass Melters-Part 1. Preliminary General Limits at Savannah River," Journal of the American Ceramic Society, 73, 10, pp. 2896-2902.

Blair, H. T., and J. M. Luckacs, 1980, Investigating of Foaming During Nuclear DefenseWaste Solidification by Electric Melting, PNL-3552, Pacific Northwest Laboratory, Richland, Washington.

Bradley, D. J., 1991, Radioactive Waste Management in the USSR: A Review of Unclassified Sources, Vol. II, PNL-7645, Pacific Northwest Laboratory, Richland, Washington.

Bunnel, L. R., 1988, Laboratory Work in Support of West Valley Glass Development, PNL-6539, Pacific Northwest Laboratory, Richland, Washington.

Notes: This report describes results of melter and glass testing for the WVDP. Provides information on glass product durability, glass melt foaming and the effect of sugar addition on foaming. Includes foam measurement in crucible melts using a variable pressure technique. Data indicates sugar addition has a negative effect on glass melting rate. Report includes some discussion of redox measurement methods and formation of secondary phases in the melt (calcium phosphate, rare earth phosphates, $\mathrm{CrFe}$ spinels, etc. Data indicates the phosphorus solubility limit in glass varies with concentration of calcium, rare earths, and possibly other components.

Burkholder, H. C., and J. H. Jarrett, 1986, Nuclear Waste Treatment Program Annual Report for FY 1985, PNL-5787, Rev. 0, Pacific Northwest Laboratory, Richland, Washington.

Burkholder, H. C., and C. R. Allen, 1987, LFCM Vitrification Technology, PNL-5904-4, Pacific Northwest Laboratory, Richland, Washington.

Calmus, R. B., 1995, High-Level Waste Melter Alternatives Assessment Report, WHC-EP-0847, Westinghouse Hanford Company, Richland, Washington. 
WHC-SD-WM-TI-735

Revision 0

Chapman, C. C., 1983, Comparison of the Rotary Calciner-Metallic Melter and the SlurryFed Ceramic Melter Technologies for Vitrifying West Valley High-Level Wastes, DOE/NE/44139-6 (DOE86010532), West Valley Nuclear Services Company, West Valley, New York.

Chick, L. A., J. L. Swanson, and D. S. Goldman, 1984, "Nuclear Waste Glass Composition Limitations," Proceedings of Fuel Reprocessing and Waste Management, Vol. 1, pp. 371-385, American Nuclear Society, Inc., LaGrange Park, Illinois.

Cooper, M. F., M. L. Elliott, L. L. Eyler, C. J. Freeman, J. J. Higginson, L. A. Mahoney, and M. R. Powell, 1994, Research-Scale Melter Test Report, PNL-9428, Pacific Northwest Laboratory, Richland, Washington.

Crow, K. R., A. F. Weisman, P. D. Guidotti, A. M. Wehner, and G. A. Griffin, 1987, Summary of Campaigns SGM-4 and SGM-5 of the Defense Waste Processing Facility Scale Glass Melter, DPST-87-247, Savannah River Laboratory, Aiken, South Carolina.

Dierks, R. D., 1980, Investigation of Corrosion Experience in a Spray Calciner/Ceramic Melter Vitrification System, PNL-3406, Pacific Northwest Laboratory, Richland, Washington.

DOE, 1981, The Evaluation and Review of Alternative Waste Forms for Immobilization of High-Level Radioactive Waste, DOE/TIC-11472, U.S. Department of Energy-Office of Nuclear Waste Management, Germantown, Maryland.

DOE, 1990, Evaluation and Selection of Borosilicate Glass as the Waste Form for Hanford High-Level Radioactive Waste, DOE/RL-90-27, Rev. 1, U.S. Department of Energy Project Technical Support Office, Washington, D.C.

DOE, 1994, High-Level Waste Borosilicate Glass A Compendium of Corrosion Characteristics, Volumes 1, 2 and 3, DOE-EM-0177, U. S. Department of Energy, Office of Waste Management, Washington D. C.

Eaton, W. C., 1995a, Test Plan: Phase I Hanford LLW Melter Tests, GTS Duratek, Inc., WHC-SD-WM-VI-020, Rev. 0, Westinghouse Hanford Company, Richland, Washington.

Eaton, W. C., 1995b, Test Plan: Phase I Demonstration of 3 Phase Electric Arch Melting Furnace Technology for Vitrifying High-Sodium Content Low-Level Radioactive Liquid Wastes, WHC-SD-WM-VI-021, Rev. 0, Westinghouse Hanford Company, Richland, Washington. 
WHC-SD-WM-TI-735

\section{Revision 0}

Eaton, W. C., 1995c, GTS Duratek, Phase I Hanford Low-Level Waste Melter Tests: Final Report, WHC-SD-WM-VI-027, Rev. 0, Westinghouse Hanford Company, Richland, Washington.

Eaton, W. C., 1995d, U.S. Bureau of Mines, Phase I Hanford Low-Level Waste Melter Tests: Final Report. WHC-SD-WM-VI-030, Rev. 0, Westinghouse Hanford Company, Richland, Washington.

Elliott, M. L., L. L. Eyler, L. A. Mahoney, M. F. Cooper, L. D. Whitney, and P. J. Shafer, 1994, Preliminary Melter Performance Assessment Report, PNL-9822, Pacific Northwest Laboratory, Richland, Washington.

Elmore, M. R., and G. A. Jensen, 1991, Materials Selection for Process Equipment in the Hanford Waste Vitrification Plant, PNL-7729, Pacific Northwest Laboratory, Richland, Washington.

Goldman, D. S., and D. W. Brite, 1986, "Redox Characterization of Simulated Nuclear Waste Glass," Journal of the American Ceramic Society, Volume 69 No. 5, May 1986.

Notes: Provides data on $\mathrm{Fe}+2 / \mathrm{Fe}+3$ on simulated HLW borosilicate glass melts as a function of temperature and oxygen pressure, data for commercial alkali borosilicate glasses is also provided for comparison.

Goldman, D. S., D. W. Brite, and W. C. Richey, 1986, "Investigation of Foaming in Liquid Fed Melting of Simulated Nuclear Waste Glass" Journal of the American Ceramic Society, Volume 69 No. 5 pp 413-417.

Notes: Laboratory crucible tests on glass foaming versus pressure and redox, review of melter behavior, analysis of gasses trapped in foam bubbles.

Goles, R. W., and C. M. Anderson, 1986, "LFCM Emission and Off-Gas System Performance for Feed Component Cesium," American Nuclear Society MeetingSpectrum '86, Richland, Washington.

Goles, R. W., and R. K. Nakaoka, 1990, Hanford Waste Vitrification Program Pilot-Scale Ceramic Melter Test 23, PNL-7142, Pacific Northwest Laboratory, Richland, Washington.

Gray, W. J., 1976, Volatility of a Zinc Borosilicate Glass Containing Simulated High-Level Radioactive Waste, BNWL-2111, Pacific Northwest Laboratory, Richland, Washington. 
WHC-SD-WM-TI-735

Revision 0

Grunewald, W., G. Roth, W. Tobie, and S. Weisenburger, 1993a, "Progress Achieved in HLW Vitrification Techniques at INE," Proceedings of the 1993 International Conference on Nuclear Waste Management and Environmental Remediation, 2:113-118, Prague, Czech Republic.

Guidotti, P. D., K. R. Crow, A. F. Weisman, M. R. Baron, and A. M. Wehner, 1987, Summary of Campaigns SGM-6 and SGM-7 of the DWPF Scale Glass Melter, DPST-87-532, Savannah River Laboratory, Aiken, South Carolina.

Notes: Describes results of two test runs with the Scale Glass Melter (about 0.4 scale with full scale melter feed and glass pour mechanical features). Besides basic melter operating performance, report includes significant information on the glass pour system, melter feed system, pump and valve performance in slurry service, and melter offgas.

Hamm, B. A. to M. A. Ebra, 1984, High Level Caves Rheological Studies of Tanks 15H, $42 H$, and $8 F$ Sludge Slurries, DPST-84-439, April 11, 1984, E. I. du Pont de Nemours \& Company, Aiken, South Carolina.

Notes: Reports results of rheology testing on actual waste from three tanks and also for three simulants. Yield stress and consistency versus suspended solids content is given based on a Bingham plastic model. The high aluminum waste and simulant are found to have much higher yield stress. Tanks 15 and 42 Yield stress ranged up to 260 dyne/ $\mathrm{cm} 2$ at $14 \mathrm{wt} \%$ insoluble solids with a rapid increase above about $10 \mathrm{wt} \%$. Tank $8 \mathrm{~F}$ ranged up to $350 \mathrm{dyne} / \mathrm{cm} 2$ at $30 \mathrm{wt} \%$ insoluble solids with a rapid increase above about $20 \mathrm{wt} \%$.

Hendrickson, D. W., 1994, Test Plan for Evaluation of Plasma Melter Technology for Vitrification of High-Sodium Content Low-Level Radioactive Liquid Wastes, WHC-SD-WM-VI-011, Rev. 0, Westinghouse Hanford Company, Richland, Washington.

Hendrickson, D. W., 1995, Evaluation of Plasma Melter Technology for Vitrification of High-Sodium Content Low-Level Radioactive Liquid Wastes -- Demonstration Test Number 4 Final Test Report, WHC-SD-WM-VI-016, Rev. 0, Westinghouse Hanford Company, Richland, Washington.

Higley, B. A., 1995a, Test Plan for Glass Melter System Technologies for Vitrification of High-Sodium Content Low-Level Radioactive Liquid Wastes, Project Number $R D D-43288$, WHC-SD-WM-VI-018, Rev. 0, Westinghouse Hanford Company, Richland, Washington. 
Higley, B. A., 1995b, Glass Melter System Technologies for Vitrification of High-SodiumContent Low-Level Radioactive Liquid Wastes--Phase I: SBS Demonstration With Simulated Low-Level Waste--Final Test Report, WHC-SD-WM-VI-024, Rev. 0, Westinghouse Hanford Company, Richland, Washington.

Hrma, P. R., and A. W. Bailey, 1995, "Waste Loading Maximization for Vitrified Hanford HLW Blend," Proceedings of the Fifth International Conference on Radioactive Waste Management and Environmental Remediation, American Society of Mechanical Engineers, New York, New York.

Hrma, P. R., and W. T. Cobb, 1991, Behavior of $\mathrm{RuO}_{2}$ in a Glass Melt, PNL-SA-19544, Pacific Northwest Laboratory, Richland, Washington.

Hrma, P. R., G. F. Piepel, M. J. Schweiger, D. E. Smith, D.-S. Kim, P. E. Redgate, J. D. Vienna, C. A. LoPresti, D. B. Simpson, D. K. Peeler, and M. H. Langowski, 1994, Property/Composition Relationships for Hanford High-Level Waste Glasses Melting at 1150 C, PNL-10359, Vol. 1 and Vol. 2, Pacific Northwest Laboratory, Richland, Washington.

Notes: Report summarizes results of test work performed by PNL from 1989 to 1994 on properties of 120 glass compositions that may be produced from Hanford Site HLW. Data correlations and models are presented together with statistical analysis of the data and models. Glass compositions studied were targeted for melters operating at approximately $1150^{\circ} \mathrm{C}$ melting temperatures. Glass properties studied were primarily those related to processability in resistance electric heated melters, and those related to immobilized HLW product quality, i.e., Viscosity, electrical conductivity, crystal formation behavior, thermal expansion coefficient, and durability (leach rate).

Hutson, N. D., 1994, Integrated DWPF Melter System (IDMS) Campaign Report: Hanford Waste Vitrification Plant (HWVP) Process Demonstration, WSRC-TR-92-0403, Rev. 1, Westinghouse Savannah River Company, Savannah River Technology Center, Aiken, South Carolina.

Jantzen, C. M., 1986, Phosphate Additions to Borosilicate Waste Glass Cause Phase Separation, DPST-86-389, Savannah River Laboratory, Aiken, South Carolina.

Jantzen, C. M., and D. F. Bickford, 1985, "Leaching of Devitrified Glass Containing Simulated SRP Nuclear Waste," Materials Research Society Symposium Proceedings.

Jantzen, C. M., N. E. Bibler, D. C. Beam, C. L. Crawford, and M. A. Pickett, 1993, Characterization of the Defense Waste Processing Facility (DWPF) Environmental Assessment (EA) Glass Standard Reference Material (U), WSRC-TR-92-346, Rev. 1, Westinghouse Savannah River Co. Savannah River Site, Aiken, South Carolina. 
Jantzen, C. M., 1991, "First Principles Process-Product Models for Vitrification of Nuclear Waste: Relationship of Glass Composition to Glass Viscosity, Resistivity, Liquidus Temperature and Durability," Ceramic Transactions, Vol. 23, pp. 37-51, Nuclear Waste Management IV, The American Ceramic Society.

Kelly, S. E., 1995, Penberthy Electromelt International, Inc. Test Plan for Phase I Low-Level Waste Vitrification Melter Demonstration, WHC-SD-WM-VI-026, Rev. 0, Westinghouse Hanford Company, Richland, Washington.

Kelm, M., B. Oser, S. Drobnik, and W. D. Deckwar, 1980, "Denitration of Aqueous Waste Solutions from the Nuclear Fuel Processing," Nuclear Technology, Vol. 51, pp.27-32.

Kim, D. S., P. Hrma, D. A. Lamar, and M. L. Elliot, 1994, "Development of High-Waste Loaded High-Level Nuclear Waste Glasses for High-Temperature Melter," Environmental and Waste Management Issues in Ceramic Industry II, pp. 39-47, American Ceramic Society, Westerville, Ohio.

Kim, D. S., and P. Hrma, 1995, "Models for Liquidus Temperature of Nuclear Waste Glasses," Ceramic Transactions, Vol. 45, American Ceramic Society, Westerville, Ohio.

Kim, D. S., P. Hrma, D. E. Smith, and M J. Schweiger, 1994, "Crystallization in Simulated Glasses from Hanford High-Level Nuclear Waste Composition Range," in Environmental and Waste Management Issues for the Ceramic Industry, pp 179-189, American Ceramic Society, Westerville, Ohio.

Kim, D. S., D. K. Peeler, and P. Hrma, 1995, Effect of Crystallization on the Chemical Durability of Simulated Nuclear Waste Glasses, PNNL-SA-27272, Pacific Northwest National Laboratory, Richland, Washington.

Kupfer, M. J. and W. W. Schulz, 1977, Fixation of Hanford Sludge by Conversion to Glass, ARH-SA-285, Atlantic Richfield Hanford Company, Richland, Washington.

Kupfer, M. J., 1979, Vitrification of Hanford Radioactive Defense Wastes, RHO-SA-89, Rockwell Hanford Operations, Richland, Washington.

Kupfer, M. J. and R. A. Palmer, 1980, Physical and Chemical Characterization of Borosilicate Glasses Containing Hanford High-Level Wastes, RHO-SA-189, Rockwell Hanford Operations, Richland, Washington.

Kupfer, M. J., 1987, Vitrification of Hanford Bismuth Phosphate and Uranium Recovery Process Sludges, RHO-LD-60, Rockwell Hanford Operations, Richland, Washington. 
WHC-SD-WM-TI-735

\section{Revision 0}

Lammerts, H., E. Mers, and S. T. Halasovich, 1985, Technetium Volatilization During HLLW Vitrification, Proceedings of Materials research Society Symposium, Vol. 44, pp. 823-829.

Larson, D. E. 1996, Hanford High-Level Waste Vitrification Program, Pacific Northwest Laboratory Technology Development, Annotated Bibliography, PNNL-10955, Pacific Northwest National Laboratory, Richland, Washington.

Lifanov, F. A., 1993, "Vitrification of Intermediate Level Liquid Radioactive Waste," Proceedings of the 1993 International Conference on Nuclear Waste Management and Environmental Remediation, American Society of Mechanical Engineers, New York, New York.

Lucktong, C., and P Hrma, 1988, "Oxygen Evolution During MnO-Mn3O4 Dissolution in a Borosilicate Melt," Journal of the American Ceramic Society, Vol. 71, pp. 323-328.

Mast, E. S., 1995, Low-Level Waste Vitrification Phase I Vendor Test Sample Analysis Data, WHC-SD-WM-DP-131, Rev. 0, Westinghouse Hanford Company, Richland, Washington.

McElroy, J. L., 1974, Quarterly Progress Report Research and Development Activities Waste Fixation Program April Through June 1974, BNWL-1841, Pacific Northwest Laboratory, Richland, Washington.

Notes: Report of a 510-h spray calciner and metallic can melter test in pages 3-25. A $\mathrm{CeO} 2$ rich sludge phase settled and was too viscous to drain. Small amounts of yellow NaMo03 were observed dispersed in the glass product. Severe corrosion of the Inconel $690^{1}$ melter was experienced (up to .07 in. in two weeks operation). Data are reported on Inconel corrosion rate as a function of agitator speed. Information on preliminary work on ceramic lined melters is also included in the report.

Merrill, R. A., and D. S. Janke, 1993, "Results of Vitrifying Fernald OU-4 Wastes," Proceedings of Waste Management '93, February 28 through March 4, Tucson, Arizona.

Moncouyoux, J. P., R. Boen, M. Puyou, and A. Jouan, 1991, New Vitrification Techniques, CEA-CONF-10556, International Conference on Nuclear Fuel Reprocessing and Waste Management, Sendai, Japan.

Mukerji, J., 1972, "Behavior of Ruthenium in Glass," Ind. Eng. Chemc. Prod. Res. Develop. 11(2): 178-83.

${ }^{1}$ Inconel and Inconel 690 are trademarks of International Nickel Company. 
Nezhentsev, V. V., Y. B. Petrov, A. A. Zhilin, and O. S. Dymshits, 1987, "Use of Induction Furnaces with a Cold Crucible for Melting Hard Glasses (Review), " Glass and Ceramics, A Translation of Steklo i Kermika, Vol. 43, No. 9-10, pp. 391-396.

Perez, J. M., and R. K. Nakaoka, (R. G. Post and M. E. Macks, editors), 1986, "Vitrification Testing of Simulated High-Level Radioactive Waste at Hanford," Proceedings of Symposium on Waste Management '86, Tucson, Arizona.

Platt, A. M., 1974, Quarterly Progress Report Research and Development Activities Waste Fixation Program October Through December 1973, BNWL-1809, Pacific Northwest Laboratory, Richland, Washington.

Notes: Summary of information on an in-can melter test (page 7). Reported increased melt rate with agitation, corrosion of Inconel 690, and melter discharge plugging with crystalline material (mainly $\mathrm{CeO} 2$ ).

Ramsey, W. G., C. M. Janzen, and D. F. Bickford, 1991, "Redox Analyses of SRS Melter Feed Slurry; Interactions Between Nitrate, Formate, and Phenol Based Dopants," Proceedings of the Fifth International Symposium on Ceramics in Nuclear and Hazardous Waste Management, Vol. 23, April 29 through May 3, 1991, Westerville, Ohio.

Notes: Provides summary of data on glass redox versus melter feed composition, focusing on nitrate and formate as primary independent variables, includes both melter data and crucible melt data.

Rasul, C. G. and M. Cable, 1966, "Spontaneous Bubble Formation in Silicate Melts at High Temperatures," Journal of American Ceramic Society, 49 [10] 568-71.

Notes: Contains information on glass foaming.

Richards, R. S., and J. W. Lacksonen, 1991, "Stir-Melter Vitrification of Simulated Radioactive Waste, Fiber Glass Scrap, and Municipal Waste Combustor Fly Ash," Nuclear Waste Management IV, 93rd Annual Meeting of the American Ceramic Society, Cincinnati, Ohio.

Rimshaw, S. J., F. N. Case, and J. A. Tompkins, 1980, Volatility of Ruthenium-106, Technetium-99, and Iodine-129, and the Evolution of Nitrogen Oxide Compounds During the Calcination of High-Level Radioactive Nitric Acid Waste, ORNL-5562, Oak Ridge National Laboratory, Oak Ridge, Tennessee.

Ritter, J. A., J. R. Zamecnik. and C. W. Hsu, 1992, "Hydrogen Generation During Treatment of Simulated High-Level Radioactive Waste with Formic Acid," Proceedings of the Third International Conference on High Level Radioactive Waste Management, April 12-16, 1992, Las Vegas, Nevada. 
Ross, W. A., and J. E. Mendel, 1980, Annual Report on the Development of Solidified Forms for High-Level Wastes: 1978, PNL-3060, Pacific Northwest Laboratory, Richland, Washington.

Notes: Indicates that cesium volatility from glass melting decreases with increased melt viscosity at constant temperature.

Ryan, J. L., 1995, Redox Reactions and Foaming in Nuclear Waste Glass Melting, PNL-10510, Pacific Northwest National Laboratory, Richland, Washington.

Schreiber, H. D., G. B. Balazs, P. L. Jamison, and A. P. Shaffer, 1982, "The Chemistry of Uranium in Borosilicate Glasses: Part 2. Base Compositions Containing Titanium Relevant to the Immobilization of Nuclear Waste," Physical Chemistry of Glasses, Vol. 23 (5): pp. 147-153.

Schreiber, H. D., G. B. Balazs, and S. J. Kozak, 1983, "Chemistry of Uranium in Glass Forming Melts with Chromium and Iron in Aluminosilicates," Journal of Ceramic Society, Vol. 66 (5): pp. 340-46.

Schreiber, H. D., and G. B. Balazs, 1982, "The Chemistry of Uranium in Borosilicate Glasses: Part I. Simple Base Compositions Relevant to Nuclear Waste Immobilization," Physical Chemistry of Glasses, Vol. 23 (5): pp. 139-46.

Schreiber, H. D., et al., 1984, "An Electromotive Force Series in a Borosilicate Glassforming Melt," Communication of the American Ceramic Society, pp. C106-C.108, June 1984.

Schreiber, H. D., G. B. Balazs, and T. N. Solberg, 1985, "The Chemistry of Uranium in Borosilicate Glasses: Part 6. The Leaching of Uranium from Glass," Physical Chemistry of Glasses, Vol. 26: pp. 35-45.

Schreiber, H. D., et al., 1986, "Redox Equilibrium and Kinetics of Iron in a Borosilicate Glass Forming Melt," Jourmal of Non-crystalline Solids, Vol. 84, p. 186-195.

Schreiber, H. D., et. al, 1982, "The Chemistry of Uranium in Borosilicate Glasses: Part 5. The Ferric-Ferrous Couple as a Potential Redox Buffer for the Uranium Redox State Distribution Against Oxidizing Agents in a Borosilicate Melt," Physical Chemistry of Glasses, Vol. 25: pp. 1-9.

Schreiber, H. D., M. W. Rietmiller, and T. P. Duggan, 1991, "Solution Chemistry of Noble Metals in a Model Nuclear Waste Glass, " Ceramic Transactions, Nuclear Waste Management IV, Vol. 23, American Ceramic Society, Westerville, Ohio.

Scott, P. A., 1985, Technology of Off-Gas Treatment for Liquid-Fed Ceramic Melters, PNL-5446, Pacific Northwest Laboratory, Richland, Washington. 
Seymore, R. G, 1995a, Evaluation of Alternative Chemical Additives for High-Level Waste Vitrification Feed Preparation Processing, WHC-SD-WM-SP-009, Rev. 0, Westinghouse Hanford Company, Richland, Washington.

Notes: This report provides a review of engineering evaluations and testing work to evaluate additives for use in HLW feed preparation as alternatives to formic acid. Preliminary evaluation and testing has identified glycolic acid as a promising alternative to formic acid. Tests with simulated Hanford Site HLW feeds indicated use of glycolic acid results in substantially reduced production of hydrogen and ammonia compared to formic acid.

Seymore, R. G, 1995b, Development of the High-Level Waste High Temperature Melter Feed Preparation Flowsheet for Vitrification Process Testing, WHC-SD-WM-SP-008, Rev. 0, Westinghouse Hanford Company, Richland, Washington.

Notes: This report summarizes the basis for selecting the feed preparation flowsheets for the first two Hanford Site HLW melter tests performed on the PNL small scale, high temperature melter (SSHTM). Two feed preparation flowsheets were selected, one included addition of nitric acid and the other included addition of glycolic acid in place of formic acid which has been used in most previous melter tests. Silica sand was also selected as the primary source of silicon.

Shade, J. W., 1994, Waste Simulant Development for Evaluation of LLW Melter System Technology, WHC-SD-WM-TI-624, Rev. 0, Westinghouse Hanford Company, Richland, Washington.

Shade, J. W., 1995, Preliminary Low-Level Waste Feed Definition Guidance -- LLW Pretreatment Interface, WHC-SD-WM-RD-052, Rev. 0, Westinghouse Hanford Company, Richland, Washington.

Smith, H. D., et al., 1994, Alternate Processing Flowsheets for Treating NCAW Waste Slurny with Formic Acid: Split Acid Addition to Reduce H2 Generation Rate and Total NH3 Production, PNL-SA-23435, Pacific Northwest Laboratory, Richland, Washington.

Smith, H. D., et al., 1995, HWVP Feed Preparation Chemistry for and NCAW Simulant, Fiscal Year 1992: Evaluation of Offgas Generation and Ammonia Formation, PNL-10369, Pacific Northwest National Laboratory, Richland, Washington.

Stegen, G. E., 1996, Vectra Phase I Low-Level Waste Melter Test Report, WHC-SD-WM-VI-031, Rev. 0, Westinghouse Hanford Company, Richland, Washington. 
Sussmilch, J., and A. Jouan, 1993, "The Vitrification of Accident Wastes from the Nuclear Power Plant A-1 in Slovakia," Proceedings of Environmental Remediation and Environmental Issues, Vol. 3, R. Buschwitz et al. eds., American Society of Mechanical Engineers.

Notes: Includes information on vitrification of wastes with high chromium content.

Watrous, R. A., O. L. Kruger, P. Hrma, and J. M. Perez, Jr., 1991, "Recycle Stream Impacts on Feed Treatment Flowsheets and Glass Formulation for the Hanford Waste Vitrification Plant, " Ceramic Transactions, Vol. 23, pp 321-332, American Ceramic Society, Westerville, Ohio.

Wiemers, K. D., 1988, Gas Release During Formatting of a Simulated Hanford Waste Vitrification Plant Feed, PNL-SA-15965, Pacific Northwest Laboratory, Richland, Washington.

Wilson, C. N., 1995a, Melter Technology Evaluation for Verification of Hanford Site Low-Level Waste, WHC-SA-2857-FP, Westinghouse Hanford Company, Richland, Washington.

Wilson, C. N., 1995b, Envitco, Inc. Phase I Test Plan for Low-Level Waste Melter Demonstration, WHC-SD-WM-VI-022, Rev. 0, Westinghouse Hanford Company, Richland, Washington.

Wilson, C. N., 1994, Evaluation of Melter System Technologies for Vitrification of High Sodium Radioactive Liquid Wastes--Statement of Work, WHC-SD-WM-RD-044, Rev. 0 Westinghouse Hanford Company, Richland, Washington.

Wilson, C. N., 1996a, Envitco Phase I Low-Level Waste Melter Test Report, WHC-SD-WM-VI-023, Rev. 0, Westinghouse Hanford Company, Richland, Washington.

Wilson, C. N., 1996b, Low-Level Waste Vitrification Phase I Melter Vendor Demonstration Testing Summary Report, WHC-SD-WM-ER-498, Rev. 0 (to be issued), Westinghouse Hanford Company, Richland, Washington.

Zhu, B. F., D. E. Clark, L. L. Hench, and G. G. Wicks, 1986, "Leaching Behavior of Nuclear Waste Inhomogeneities," Journal of Non-Cystalline Solids, Vol. 80, No. 1-3, pp. 324-334. 
WHC-SD-WM-TI-735

Revision 0

\subsection{SEPARATION OF RADIONUCLIDES FROM LIQUID TANK WASTES}

Bray, L. A., K. J. Carson, and R. J. Elovich, 1993, Initial Evaluation of Sandia National Laboratory Prepared Crystalline Silicotitanates for Cesium Recovery, PNL-8847, Pacific Northwest Laboratory, Richland, Washington.

Brown, G. N., L. A. Bray, C. D. Carlson, K. J. Carson, J. R. DesChane, R. J. Elovich, F. V. Hoopes, D. E. Kurath, L. L. Nenninger, and P. K. Tanaka, 1996, Comparison of Organic and Inorganic Ion Exchangers for the Removal of Cesium and Strontium from Simulated and Actual Hanford 241-AW-101 DSSF Tank Waste, PNL-10920, Pacific Northwest National Laboratory, Richland, Washington.

Notes: This report compares organic (resorcinol-formaldehyde (RF), SuperLig-644², Duolite CS- $100^{3}$ resins) and inorganic materials (sodium titanate, IONSIV TIE-96, crystalline silico-titanates [IONSIV IE-910, powder; IONSIV IE-911, engineered form]) for separation of cesium and strontium from simulants and actual Hanford Site tank waste.

Brown, G. N., L. A. Bray, R. J. Elovich, 1995, Evaluation of SuperLig-644, Resorcinol-Formaldehyde and CS-100 Ion Exchange Materials for the Removal of Cesium from Simulated Alkaline Supernate, PNL-10486, Pacific Northwest National Laboratory, Richland, Washington.

Notes: This report compares resorcinol-formaldehyde (RF), SuperLig-644, Duolite CS-100 resins for separation of cesium from simulated neutralized current acid waste (NCAW) supernatant. Cesium batch distribution coefficients, column loading and elution profiles, and eluate compositions are provided for each ion exchanger.

Brown, G. N., et al., 1995, Chemical and Radiation Stability of SuperLig-644, Resorcinol-Formaldehyde and CS-100 Ion Exchange Materials, PNL-10772, Pacific Northwest National Laboratory, Richland, Washington.

Notes: The chemical and radiation stability of SuperLig-644, Resorcinol-Formaldehyde and Duolite CS-100 cesium ion exchange resins are evaluated in 1 molar $\mathrm{NaOH}$ and simulated NCAW supernatant.

\footnotetext{
${ }^{2}$ SuperLig 644 is a registered trademark of ICB Technologies, Inc., Provo, Utah.

${ }^{3}$ Duolite CS-100 is a trademark of Rohm and Haas, Philadelphia, PA.
} 
Eager, K. M., D. L. Penwell, and B. J. Knutson, 1994, Preliminary Flowsheet: Ion Exchange Process for the Separation of Cesium from Hanford Tank Waste Using Duolite CS-100 Resin, WHC-SD-WM-TI-667, Westinghouse Hanford Company, Richland, Washington.

Notes: This report provides a preliminary flowsheet concept for cesium ion exchange processing of double-shell slurry feed (DSSF) and NCAW. A bibliography of cesium ion exchange reports using Duolite CS-100 resin is provided.

Kurath, D. E., et al., 1994, Experimental Data and Analysis to Support the Design of an Ion Exchange Process for the Treatment of Hanford Tank Waste Supernatant Liquids, PNL-10187, Pacific Northwest National Laboratory, Richland, Washington.

Notes: This report provides cesium batch distribution coefficients and 200-ml scale column test results for separation of cesium from simulated DSSF and NCAW solutions using resorcinol formaldehyde and Duolite CS-100 resins. Correlations are provided for determining cesium distribution coefficients at various sodium, potassium and cesium concentrations.

Penwell, D. L., K. M. Eager, and B. J. Knutson, 1994, Preliminary Flowsheet: Ion Exchange Process for the Separation of Cesium from Hanford Tank Waste Using Resorcinol Formaldehyde Resin, WHC-SD-WM-TI-638, Westinghouse Hanford Company, Richland, Washington.

Notes: This report provides a preliminary flowsheet concept for cesium ion exchange processing of DSSF and NCAW. A biliography of cesium ion exchange reports using resorcinol formaldehyde resin is provided.

Schroeder, N. C., et al., 1995, Technetium Partitioning for the Hanford Tank Waste Remediation System: Alternative Technologies for Separating Technetium from Synthetic DSSF, LA-UR-95-4290, Los Alamos National Laboratory, Los Alamos, New Mexico.

Notes: Technetium distribution coefficients are provided for water-soluble polymers and solvent extractants from simple solutions, high nitrate simulants, and DSSF simulants. 
WHC-SD-WM-TI-735

\section{Revision 0}

Schroeder, N. C., et al., 1995, Technetium Partitioning for the Hanford Tank Waste Remediation System: Anion Exchange Studies for Partitioning Technetium from Synthetic DSSF and DSS Simulants and Actual Hanford Wastes (101-SY and 103-SY) Using Reillex-HPQ Resin, LA-UR-95-4440, Los Alamos National Laboratory, Los Alamos, New Mexico.

Notes: This report provides technetium batch distribution coefficients, laboratory scale breakthrough and elution profiles for partitioning from synthetic and actual Hanford Site wastes. 
WHC-SD-WM-TI-735

Revision 0

\subsection{INTEGRATED SYSTEMS STUDIES, FLOWSHEETS, AND MISCELLANEOUS SUPPORTING DOCUMENTS}

Boomer, K. D., S. K. Baker, A. L. Boldt, J. D. Galbraith, J. S. Garfield, C. E. Golberg, B. A. Higley, L. J. Johnson, M. J. Kupfer, R. M. Marusich, R. J. Parazin, A. N. Praga, G. W. Reddick, J. A. Reddick, E. J. Slaathaug, L. M. Swanson, T. L. Waldo, and C. E. Worcester, 1993, Tank Waste Technical Options Report, WHC-EP-0616, Rev. 0, Westinghouse Hanford Company, Richland, Washington.

Boomer, K. D., J. M. Colby, T. W. Crawford, J. S. Garfield, J. D. Galbraith, C. E. Golberg, C. E. Leach, D. E. Mitchell, F. D. Nankani, E. J. Slaathaug, L. M. Swanson, T. L. Waldo, and C. M. Winkler, 1994, Tank Waste Remediation System Facility Configuration Study, WHC-SD-WM-ES-295, Rev. 0, Westinghouse Hanford Company, Richland, Washington. Note: See Appendix C, "Detached High-Level Waste Treatment Facility."

DOE, 1988, Disposal of Hanford Defense High-Level, Transuranic, and Tank Wastes, Hanford Site, Richland, Washington; Record of Decision, Federal Register, Vol. 53, No. 72, pp. 12449-12453, U.S. Department of Energy, Washington, D.C.

DOE, 1986, Waste Acceptance Preliminary Specifications for the Defense Waste Processing Facility High-Level Waste Form, OGR/B-8, U.S. Department of Energy-Office of Civilian Radioactive Waste Management, Washington, D.C.

DOE, 1987, Final Environmental Impact Statement: Disposal of Hanford Defense HighLevel, Transuranic and Tank Wastes, Hanford Site, Richland, Washington, 5 Vols., DOE/EIS-0113, U.S. Department of Energy, Washington, D.C.

Kalia, J., 1992a, Hanford Waste Vitrification Plant Project Technical Data Package, WHC-SD-HWV-DP-001, Rev. 6, Westinghouse Hanford Company, Richland, Washington.

Kalia, J., 1992b, Hanford Waste Vitrification Plant Project Functional Design Criteria, WHC-SD-HWV-FDC-001, Rev. 5, Westinghouse Hanford Company, Richland, Washington.

Manuel, A. F., 1995, Material Balance for Alternative Melter Low-Level Waste Process Flowsheets, WHC-SD-WM-ES-354, Rev. 0, Westinghouse Hanford Company, Richland, Washington. 
WHC-SD-WM-TI-735

Revision 0

Merrill, R. A., and C. C. Chapman, 1993, "Preliminary Estimates of Cost Savings for Defense High-Level Waste Vitrification Options," Proceedings of the 1993 International Conference on Nuclear Waste Management and Environmental Remediation.

Orme, R. M., 1995, TWRS Process Flowsheet, WHC-SD-WM-TI-613, Rev. 1, Westinghouse Hanford Company, Richland, Washington.

Notes: Describes an example process design concept with a preliminary overall flow sheet and material balance for processing Hanford Site DST and SST waste.

RHO, 1980, Technical Aspects of Long-Term Management Alternatives for the High-Level Defense Waste at the Hanford Site, RHO-LD-141, Rockwell Hanford Operations, Richland, Washington.

RHO, 1985, Hanford Defense Waste Disposal Alternatives Engineering Support Data for the HDW-EIS, RHO-RE-ST-30 P, Rockwell Hanford Operations, Richland, Washington.

Shah, K. R., 1993, HWVP Increased Production Capacity Evaluation (Phase 1), WHC-SD-HWV-ES-046, Rev. 0, Westinghouse Hanford Company, Richland, Washington.

Notes: This report provides a summary of an engineering study to evaluate feasibility of substantial increasing capacity of HWVP with minimal design impacts to the fixed facility. This report indicates capacity increase up to about four times the baseline capacity can likely be achieved through use of advanced melters. Limited changes were identified to the remote process building and more extensive changes to external support facilities were identified to allow the required capacity increase. 


\begin{tabular}{|c|c|c|c|c|c|c|}
\hline \multicolumn{7}{|c|}{ DISTRIBUTION SHEET } \\
\hline \multirow{2}{*}{$\begin{array}{l}\text { To } \\
\text { Distribution }\end{array}$} & \multirow{2}{*}{\multicolumn{4}{|c|}{$\begin{array}{l}\text { From } \\
\text { Process Technology }\end{array}$}} & \multicolumn{2}{|l|}{ Page 1 of 1} \\
\hline & & & & & \multicolumn{2}{|c|}{ Date $02 / 15 / 96$} \\
\hline \multicolumn{5}{|l|}{ Project Title/Work Order } & \multicolumn{2}{|c|}{ EDT No. 608993} \\
\hline \multicolumn{5}{|c|}{$\begin{array}{l}\text { High-level Waste Process and Product Data Annotated } \\
\text { Bibliography, WHC-SD-WM-TI-735, Rev. } 0\end{array}$} & \multicolumn{2}{|l|}{ ECN No. N/A } \\
\hline Name & & MSIN & $\begin{array}{l}\text { Text } \\
\text { With All } \\
\text { Attach. }\end{array}$ & Text Only & $\begin{array}{l}\text { Attach./ } \\
\text { Appendix } \\
\text { Only }\end{array}$ & $\begin{array}{l}\text { EDT/ECN } \\
\text { Only }\end{array}$ \\
\hline
\end{tabular}

Central Files

Public Reading Room

R. B. Calmus

D. K. Carter

R. P. Colburn

J. S. Garfield

R. L. Gibby

B. A. Higley

M. E. Johnson

S. L. Lambert

R. M. Orme

R. W. Powell (2)

J. W. Shade

G. E. Stegen (5)

D. J. Washenfelder

C. N. Wilson

$\begin{array}{ll}A 3-88 & X \\ A 1-65 & X\end{array}$

H5-27

G3-21

H5-27

H5- 49

H5-27

H5-27

H5- 49

H5-27

H5-27

G3-21

H5-27

H5-27

H5-27

H5-27
$X$
$X$

$x$

$x$

$x$

$x$

$x$

$x$

$x$

$x$

$x$

$\mathrm{X}$

$x$

$\mathrm{X}$

$x$

Pacific Northwest Laboratory
C. J. Freeman
M. L. Elliott
P7-41
P7-41
P7-19
G. A. Whyatt
K6-51
$X$
$X$
$X$
$X$

U. S. Department of Energy - Richland Operations

N. R. Brown

D. D. Button

K6-51

R. Carreon

K6-51

K6-51

J. C. Peschong

K6-51

$x$

G. H. Sanders

S7 -53

$x$
$x$
$x$ 